\title{
Race and U.S. medical experimentation: the case of Tuskegee
}

\author{
Raça e experimentação médica nos Estados \\ Unidos: o caso de Tuskegee
}

\section{Raza y experimentación médica en los Estados Unidos: el caso de Tuskegee}

In 1932 the county seat of Macon County, Alabama - the small town of Tuskegee - was one of the poorest towns in the United States. It was (and remains) an area marked by old plantations, sawmills, beautiful forests, and hard-scrabble living for the predominately African-American population. In 1932 they made their living as sharecroppers, picking cotton in the surrounding fields for a median income of USD 1 per day. A 1929 study found a high incidence of syphilis in the area. Ironically, that study aimed to explore possibilities for mass treatment using the ineffective treatments then available. But the depression followed and funds ran out.

To understand what happened next at Tuskegee we need to consider the context. This was a time when many new scientific ideas were being developed. Scientists divided humankind into different "races”. Each race was thought to have certain essential characteristics, and those racial characterizations had real, practical implications. For example, the noted American geneticist Charles Davenport opined that the influx of blood from Southeastern Europe will rapidly make the American population "darker in pigmentation, smaller in stature, more mercurial... more given to crimes of larceny, kidnapping, assault, murder, rape, and sex-immorality" 1.

A logical corollary to such racialized thinking was the notion that diseases would manifest differently in different races. Ever since the 1882 advent of the germ theory, physicians had been especially interested in understanding infectious diseases, such as syphilis. The only major study on the natural history of syphilis had been done using an almost entirely Caucasian population in Oslo, Norway. U.S. physicians wanted to know if syphilis would have a different natural history in African-Americans. One reason for their curiosity was that late syphilis was known to affect the central nervous system. Investigators questioned if relatively "primitive" and "underdeveloped" black brains would be spared. Other racist ideas about African-American people and sexually transmitted diseases supported the idea of the Tuskegee experiments. U.S. Public Health Service (PHS) physician Thomas Murrell said: "Those that are treated are only half cured, and the effort to assimilate a complex civilization drives their diseased minds until the results are criminal records. Perhaps here, in conjunction with tuberculosis, will be the end of the negro problem" 2. Taliford Clark, also of the PHS explained that "Macon County is a natural laboratory; a ready-made situation. The rather low intelligence of the Negro population, depressed economic conditions, and the common promiscuous sex relations not only contribute to the spread of syphilis but the prevailing indifference with regards to treatment" 2.
${ }^{1}$ University of Michigan, Ann Arbor, U.S.A.

Correspondence J. Howell University of Michigan. Department of History - 435 South State Street, Ann Arbor MI 48109-1003, U.S.A.

jhowell@umich.edu 
And so in 1932, the PHS, assuming that these people with syphilis would never be treated, decided to use Tuskegee for a "study in nature" to determine the natural history of untreated syphilis in black men. Some 400 patients with the disease were selected for the study; 200 others served as controls. Patients were not told that they had syphilis, only of "bad blood". The study was originally intended to last only 6 months, but was extended to look at autopsy findings 3 .

PHS physicians regularly came down to Alabama to examine the men. They consistently lied to them about the study, even while trying to convince them to undergo invasive diagnostic procedures such as lumbar punctures. The Tuskegee Institute was involved. Founded by Booker T. Washington to educate freed slaves, it was run by and for the benefit of African-Americans. It had established a hospital in 1891, and in 1922 the first post-graduate course for black nurses. The Institute "volunteered" to assist with study exams and autopsies, a decision perhaps influenced by the fact that it received significant federal funding. Also key to the study was a graduate of the Tuskegee nursing school, Eunice Rivers. She was herself from Macon County, she was familiar with the environment, and she had the trust of the men involved in the study, all of which were essential for the study to proceed 4 .

Having embarked on the study, the PHS went to great lengths to keep the men from treatment, even with the ineffectual treatments then available. They asked Macon County physicians not to treat the men. When the Alabama Health Department took a mobile VD testing unit into the area in the early 1940s, the PHS made sure that study subjects would not be tested. During World War II, knowing that if the men were drafted, they would be treated, study organizers made sure that none of the patients were drafted. One man in the study suspected that he had the disease and tried to get treatment. He made it all the way to a public health clinic in Birmingham. But, the experimenters called ahead, and he was turned back.

This study did not end after the widespread availability of penicillin as an (extremely effective) treatment for syphilis in the late 1940s, nor after the high-profile Nuremberg Trials, add their promulgation of a code of medical ethics in 1947, nor the 1964 Helsinki Declaration.

Perhaps the experiments could have persisted because no one knew they were going on. Yet as early as 1936 results were presented at the highest-profile scientific meetings and published in the best medical journals. Yet the findings were banal. In 1955 the investigators concluded that "life expectancy ages 25-50 years is reduced by about 17\%". In 1964, long after penicillin had become standard therapy for tertiary syphilis, investigators stated that these men offered an "unusual opportunity" and revised the previous estimate of the decrease in life expectancy to $20 \%$. All of these studies concluded, not surprisingly, that mortality and morbidity was higher in the group with untreated syphilis. As a member of the panel later convened to review the study said, "They proved a point, then proved a point, then proved a point" 2 .

The study lasted through the U.S. Civil Rights Movement and Martin Luther King's I Have a Dream speech at the 1963 March on Washington, D.C. It lasted, believe it or not, through a meeting called by the Centers for Disease Control and Prevention (CDC) director in February 1969 specifically to discuss whether the study should be continued. Those who wanted to keep on denying these men treatment insisted that "You will never have another opportunity like this; take advantage of it". The men were seen as study subjects, not patients 2 . As one PHS physician said in another context, "We have no further interest in these men until they die" 5 . The study continued.

The study finally ended when a social worker and epidemiologist working for the CDC, Peter Buxton, provided a newspaper reporter friend with the key information about the study. On July 26 , 1972, news of the Tuskegee Experiments broke around the country. The Associated Press Wire led with: "Syphilis Victims in US Study Went Untreated for 40 Years". Shortly afterwards the PHS terminated the study.

The impact of the study was not long in coming. In 1973, Senate hearings chaired by a young senator from Massachusetts, Edward Kennedy, led to the 1974 National Commission for the Protection of Human Subjects in Biomedical and Behavioral Research. Their 17-volume report led to an Institutional Review Board (IRB) system in the United States that is intended, among other things, specifically to protect vulnerable groups from exploitation.

In 1972, 74 study subjects were still alive. At least 28, possibly as many as 100, had died from syphilis. In 1974 a class-action lawsuit awarded 70 survivors USD 37,500 each; the families of those 
who had died got USD 15,000. On May 16, 1997, in the East Room of the White House, U.S. President William Jefferson Clinton issued a poignant apology. The last study participant died in January 2004 at the age of 976 .

The Tuskegee studies have since become part of American popular lore. They stand as examples of how structural racism allowed perpetuation of the study for 40 years. They are also symbolic, and possibly causal, of continued distrust of the health care system by African-American men, who are less likely to engage in preventive care, enroll in clinical trials, follow physicians' advice, or become organ donors. This may contribute to observed racial health disparities. Furthermore, the legacy of the experiments has extended beyond the borders of the U.S. Some critics have invoked the experiments to criticize human experiments in Africa; others have questioned whether such citation is appropriate 7. They also were connected to similar studies in Guatemala, where from 1946 to 1948, a team of researchers funded by the U.S. government, including some who had worked on the Tuskegee study, went a step further and intentionally infected men and women prisoners, military personnel, patients in a mental institution, and others with sexually transmitted diseases 8 .

These recent revelations in 2010 led to high-level apologies of the U.S. government to Guatemalan leaders as well as to a detailed report by a presidential panel that demonstrated how Tuskegee frames global perceptions of bioethics and health justice ${ }^{9,10}$.

1. Davenport C. Heredity in relation to eugenics. New York: Henry Holt; 1911.

2. Brandt AM. Racism and research: the case of the Tuskegee Syphilis Experiment. In: Reverby SM, editor. Tuskegee's truths: rethinking the Tuskegee Syphilis Study. Chapel Hill: University of North Carolina Press; 2000. p. 15-33.

3. Jones J. Bad blood: the Tuskegee syphilis experiment. New York: Free Press; 1992.

4. Reverby SM, editor. Tuskegee's truths: rethinking the Tuskegee Syphilis Study. Chapel Hill: University of North Carolina Press; 2000.

5. Letter from OC Wenger to RA Vonderlehr, July 21, 1933. In: Reverby SM, editor. Tuskegee's truths: rethinking the Tuskegee Syphilis Study. Chapel Hill: University of North Carolina Press; 2000. p. 84-6.
6. Reverby SM. Examining Tuskegee: the infamous syphilis study and its legacy. Chapel Hill: University of North Carolina Press; 2013.

7. Benatar SR, Singer PA. A new look at institutional research ethics. BMJ 2000; 321:824-6.

8. Reverby SM. "Normal exposure" and inoculation syphilis: a PHS "Tuskegee” doctor in Guatemala, 1946-1948. Journal of Public History 2011; 23:6-28.

9. Fairchild AL, Bayer R. Uses and abuses of Tuskegee. Science 1999; 284:919-21.

10. United States Presidential Commission for the Study of Bioethical Issues. Ethically impossible' STD research in Guatemala from 1946 to 1948. Washington DC: Presidential Commission for the Study of Bioethical Issues; 2011.
Submitted on $06 /$ Oct $/ 2016$

Final version on $06 / \mathrm{Jan} / 2017$

Approved on 25/Jan/2017 